\title{
コンクリートの長期物性モニタ ON THE LONG TERM PROPERTIES OF リング試験 CONCRETE
}

\section{尾嵭昌彦—*1 大藤信雄 一 \\ 北川高史—— - 3 小野 香— $* 4$ \\ キーワード : \\ コンクリート, モニタリング, PCCV, 現地暴露, 圧縮強度}

Keywords :

Concrete, Monitoring, PCCV, Local exposure, Compressive strength

\section{Masahiko OZAKI — $* 1 \quad$ Nobuo OOFUJI - $* 2$ \\ Takashi KITAGAWA - $* 3 \quad$ Kaoru ONO $* 4$}

A local exposure test of concrete miniature models, which imitated the Prestressed Concrete Containment Vessel (PCCV), is being done in the Kansai Electric Power Oi Power Plant. The miniature are exposed to the environment identical to the actual PCCV's in a long term. The concrete of the miniature are tested to measure a compressive strength, an elastic coefficient, a neutralization depth, and a chloride content measurement, etc. to observe the changes of material properties. Ten years has passed and the durability and stability of the concrete model were observed by test results.

\section{1.はじめに}

鉄筋コンクリート構造物を長期にわたりモニタリングし、その物 性等について研究・報告した例は少ない。原子力発電所のような重 要構造物については特にその調査検討は重要である。

関西電力森大飯発電所 3,4 号機においては、ブレストレストコン クリート製格納容器（以下 PCCV と記す）を模擬したコンクリー 卜試倹体を作製し、平成元年 2 月より当地に暴露して、実機と同条 件下で長期的にモニタリングし、各種試験を行っている。

本報ではその 10 年目までの試験結果を報告する。

\section{2. 试鈋撮要}

\section{$2.1 P C C V の$ 概要}

PCCV の全景を写真一 1 に示す。

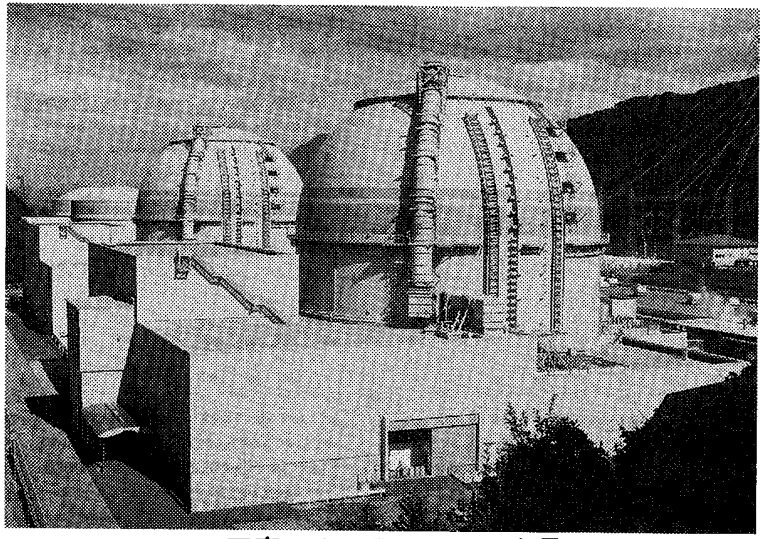

写矛-1 PCC Vの全量
PCCV は、頂部がドーム状の円筒形構造物で、PC 鋼より線によ るアンボンドプレストレストコンクリート構造である。形状は高さ $66 \mathrm{~m}$, 内径 $43 \mathrm{~m}$, 壁厚はドーム部 $1.1 \mathrm{~m}$, 円筒部 $1.3 \mathrm{~m}$ で、発電 所構内の海岸から約 $280 \mathrm{~m}$ 付近に位置している。コンクリートの設 計基準強度は $450 \mathrm{~kg} \mathrm{f} / \mathrm{cm}^{2}$ ( $44.1 \mathrm{~N} / \mathrm{mn}^{\mathbb{2}}$ ) である。

PCCV 及び暴露場の位置を示した大飯発電所構内配置を図一 1 に 示す。暴露場は当初（PCCV 建設中） は海岸付近で、平成 3 年 7 月に $\mathrm{PCCV}$ 付近に移設している。

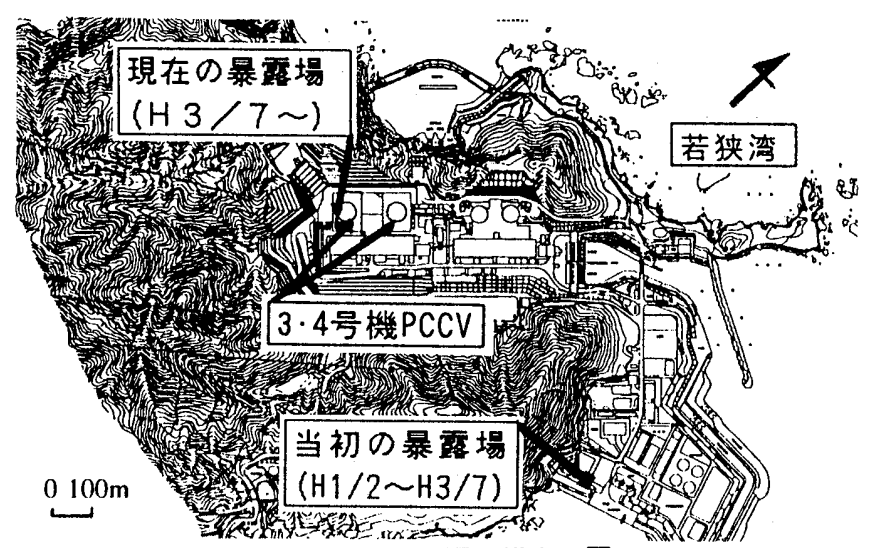

图一 1 大钣発電所撒内配曾

\section{2 试酫体の榴要}

試験体は PCCV 円筒部断面の一部を模擬した A 試験体を主体に、 外壁塗装無しの場合との諸物性比較用のB 試験体、特定の試験にあ わせた $\mathrm{C} \sim \mathrm{E}$ 試験体の合計 5 種計画した。コンクリート強度と打設

\footnotetext{
Chief Manager, Office of Civil Eng. and Architecture, the Kansai Electric Power Co., Inc.

*2 Chief Manager, Office of Wakasa, the Kansai Electric Power Co., Inc.

*3 Office of Civil Eng. and Architecture, the Kansai Electric Power Co., Inc.
}

$* 3$ 関西電力怢土木建築室 (研究当時 若狭支社)

( 5 530-8270 大阪市北区中之島3丁目3番22号)

*4 近畿コンクリート工業俶土木事業部 課長 
時期との関係を把握するため、 $\mathrm{A}$ 及び $\mathrm{C}$ 試験体は春季（4月），夏 季（7月）, 冬季（2月）の 3 季節別に作製した。その他の試験体 は春季に作製した。

図一 2 に A, B及びD試験体の外観形状を示す。A及びB試験体 は同一形状で、PCCVの円筒部を模擬した厚さ $(130 \mathrm{~cm})$ である。 $\mathrm{A}$ 試験体の屋外側となる面は実機と同様伸張型の複層仕上げ塗材を

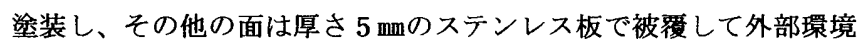
を遮断した。B試験体は、屋外及び屋内側に相当する面は無塗装の コンクリート打ち放し、その他の面は厚さ $5 \mathrm{~mm}$ のステンレス板で被 覆した。セメントの水和反応による発熱の影響を、実機の円筒部断 面の一部と同様に模擬するため、両試験体とも左右両側面と上下面 を厚さ $200 \mathrm{~mm}$ の発泡スチロールで巻き込んでコンクリートを打設し、 断熱状態で初期 2 週間の養生を行った。また、A及び $\mathrm{B}$ 試験体打設 時の屋外側面の型枠は、実機の外壁面に適用している緎維型枠（多 数の小孔をあけた合板にポリエステル䄉維を内貼りしたもの）を採 用し、打設後 3 日で脱型した。 $\mathrm{A}$ 試験体は春季, 夏季, 冬季ごとに 1 体ずつ計 3 体, B 試験体は春季に 1 体作製し、全て屋外暴露とし た。写真一 2 にA試験体の暴露状況を示す。

$\mathrm{C}$ 試験体注 $\phi 10 \times 20 \mathrm{~cm}$ の標準シリンダー形である。春季, 夏季, 冬季ごとに 24 体ずつ、計 72 体作製した。荃生箱内で 1 日, 室内で 2 日間の楸生後脱型し、材齢 13 週まで標準盖生、その後は現場封 絾養生とした。

$\mathrm{D}$ 試験体は、図一 2 に示すようにかぶり厚さを $2,4,6$, 及び $8 \mathrm{~cm}$ の 4 段階に変えて鉄筋（SD390(D51））を埋設し、叙装有無別に 3 体 ずつ、計 6 体作製した。屋外で 2 週間のシート養生後脱型し、屋外 暴露とした。

$\mathrm{E}$ 試験体は $10 \times 10 \times 40 \mathrm{~cm}$ 角柱状で、5体を作製した。養生 箱内及び室内で各々 1 日の羡生後脱型し、材踰 13 週まで標準養生、 その後は現場封絾養生とした。

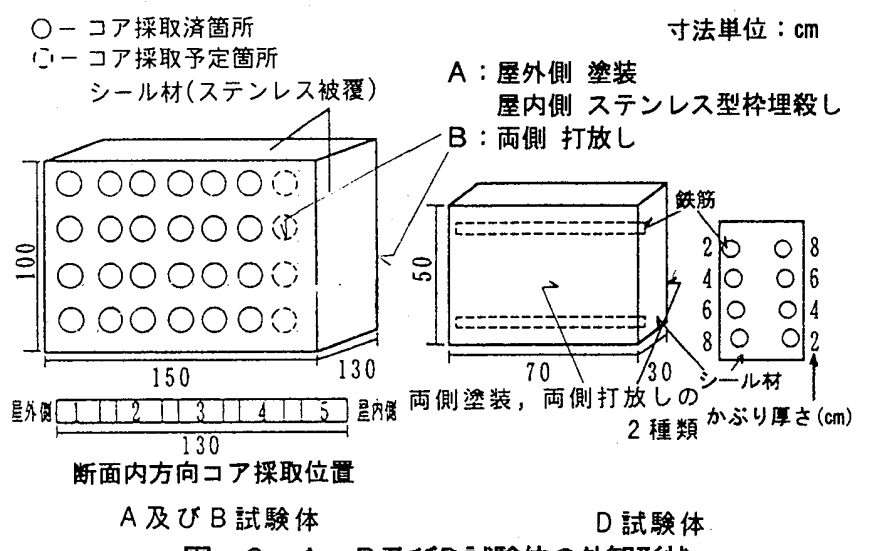

图一2 A，B及びD試験体の外穓形状

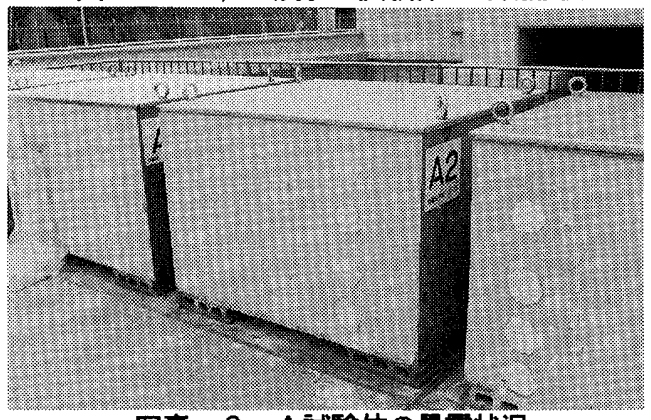

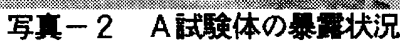

いずれの試験体もコンクリート材料と調合は共通であり、奏機 PCCV の代表調合と同じとした。表－1にコンクリート調合を示す。 フライアッシュ量はセメントの内割で $18.5 \%$ に相当する。

コンクリートの製造は、全て発電所構内に設けた水平 2 軸型強制 練りのミキサーを備えたバッチャープラントで行い、流動化剤の添 加練混ぜは打設直前に行った。

夏季に打設したコンクリートは、温度応力の低減と長期強度の増 進をねらいとして、トラックアジテータへの液体㗧素の直接投入に よるプレクーリングを実施した。また冬季は、打設後の気温低下を 考慮して練混ぜ水に温水を用いた。

表ー 1 コンクリート調合

\begin{tabular}{|c|c|c|c|c|c|c|c|c|c|c|}
\hline \multirow[b]{2}{*}{ 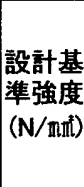 } & \multirow[b]{2}{*}{$\begin{array}{c}\text { スランフ } \\
(\mathrm{cm})\end{array}$} & \multirow[b]{2}{*}{$\begin{array}{c}\text { 空気宣最 } \\
\text { (\%) }\end{array}$} & \multirow{2}{*}{$\begin{array}{l}\text { 水結 } \\
\text { 合材 } \\
\text { 比 } \\
(\%)\end{array}$} & \multirow[b]{2}{*}{$\begin{array}{c}\text { 細骨 } \\
\text { 材率 } \\
(\%)\end{array}$} & \multicolumn{6}{|c|}{ 単位量 $\left(\mathrm{kg} / \mathrm{m}^{3}\right)$} \\
\hline & & & & & 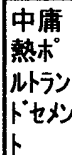 & $\begin{array}{l}7 \overline{7} \\
1 \\
7 \% \\
\vdots\end{array}$ & 水 & $\begin{array}{l}\text { 細骨 } \\
\text { 材 }\end{array}$ & \begin{tabular}{|l} 
粗骨 \\
材
\end{tabular} & \begin{tabular}{|l|} 
AE減 \\
水绪
\end{tabular} \\
\hline 44.1 & $8 \rightarrow 15$ & $4 \pm 1$ & 39.0 & 43.7 & 332 & 75 & 159 & 758 & 1003 & 4.48 \\
\hline
\end{tabular}

\section{3 试馬食項目}

表 -2 に試験項目, 表 -3 に試験材齢と試験体数及び図 -3 にA 試験体での試験手順例をそれぞれ示す。

$\mathrm{ABびB}$ 試験体については各材嚙，各季節ごとに、図一 2 に示す ○印の位置で水平方向に 4 本（長さ $1.3 \mathrm{~m}$ ) 高さ位置を変えて切り 抜き、断面方向の特性を求めるためさらに 5 本に切断し、合計 20 個のコア（以下 A， Bコア供試体と記す）を作製し、各種試験を行 った。試験体のコアを切り抜いた孔には硬練りのモルタルを圧入し、 孔周辺への影響を避けるように復旧した。C試験体は各材齢，各季 節ごとに 3 体ずつ、各種試験を行った。D試験体は暴露 5 年以降、 各材齢ごとに塗装有無別に 1 体ずつ、 $\mathrm{E}$ 試験体は各材齢ごとに 5 体 ずつ、それぞれ試験を行った。

\section{表 -2 試験項目}

\begin{tabular}{|c|c|c|c|c|c|c|c|c|c|}
\hline $\begin{array}{l}\text { 試 } \\
\text { 体 } \\
\text { 種 } \\
\text { 口 }\end{array}$ & 試験項目 & $\begin{array}{l}\text { 温 } \\
\text { 度 } \\
\text { 測 } \\
\text { 定 }\end{array}$ & $\begin{array}{l}\text { 厓 } \\
\text { 縮 } \\
\text { 強 } \\
\text { 度 }\end{array}$ & $\begin{array}{l}\text { 静 } \\
\text { 弾 } \\
\text { 性 } \\
\text { 係 } \\
\text { 数 }\end{array}$ & $\begin{array}{l}\text { 動 } \\
\text { 弾 } \\
\text { 性 } \\
\text { 係 } \\
\text { 数 }\end{array}$ & $\begin{array}{l}\text { 中 } \\
\text { 性 } \\
\text { 化 } \\
\text { 深 } \\
\text { さ }\end{array}$ & $\begin{array}{l}\text { 塩 } \\
\text { 化 } \\
\text { 物 } \\
\text { 量 }\end{array}$ & $\begin{array}{l}\text { 鉄 } \\
\text { 管 } \\
\text { の } \\
\text { 性 } \\
\text { 状 }\end{array}$ & $\begin{array}{l}\text { 長 } \\
\text { さ } \\
\text { 変 } \\
\text { 化 }\end{array}$ \\
\hline 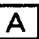 & 春季·夏季·冬季 & $\mathrm{O}$ & (2) & () & ()) & (2) & ()) & - & - \\
\hline B & 春季 & - & (9) & (2) & () & (2) & (9) & - & - \\
\hline C & 春季·夏季·冬季 & - & 0 & 0 & 0 & - & - & - & - \\
\hline $\mathrm{D}$ & 春季 & - & - & - & - & - & $\mathrm{O}$ & 0 & - \\
\hline$E$ & 春季 & - & - & - & 0 & - & - & - & $\mathrm{O}$ \\
\hline
\end{tabular}

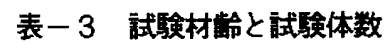

\begin{tabular}{|c|c|c|c|c|c|c|c|c|c|c|}
\hline \multirow{2}{*}{$\begin{array}{l}\text { 理 } \\
\text { 別 }\end{array}$} & \multirow{2}{*}{$\begin{array}{r}\text { 試睡体の寸法 } \\
(\mathrm{cm})\end{array}$} & \multirow{2}{*}{$\begin{array}{l}\text { 数 } \\
\text { 吾 }\end{array}$} & \multicolumn{8}{|c|}{ 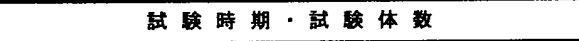 } \\
\hline & & & 4週 & 13週 & 6ヶ月 & 1年 & 2年 & 5年 & 10年 & $\begin{array}{l}\text { 20年 } \\
\text { (予定) }\end{array}$ \\
\hline A & $100 \times 150 \times 130$ & 3 & - & $20 \times 3$ & $20 \times 3$ & $20 \times 3$ & $20 \times 3$ & $20 \times 3$ & $20 \times 3$ & $20 \times 3$ \\
\hline B & $100 \times 150 \times 130$ & 1 & - & $20 \times 1$ & $20 \times 1$ & $20 \times 1$ & $20 \times 1$ & $20 \times 1$ & $20 \times 1$ & $20 \times 1$ \\
\hline c & $\phi 10 \times 20$ & 72 & $3 \times 3$ & $3 \times 3$ & $3 \times 3$ & $3 \times 3$ & $3 \times 3$ & $3 \times 3$ & $3 \times 3$ & $3 \times 3$ \\
\hline D & $50 \times 70 \times 30$ & 6 & - & - & - & - & - & 2 & 2 & 2 \\
\hline $\mathrm{E}$ & $10 \times 10 \times 40$ & 5 & 5 & 5 & 5 & 5 & 5 & 5 & 5 & 5 \\
\hline
\end{tabular}

A，Bの試験体数は、試験体から切り抜いたコア供試体の個数である 


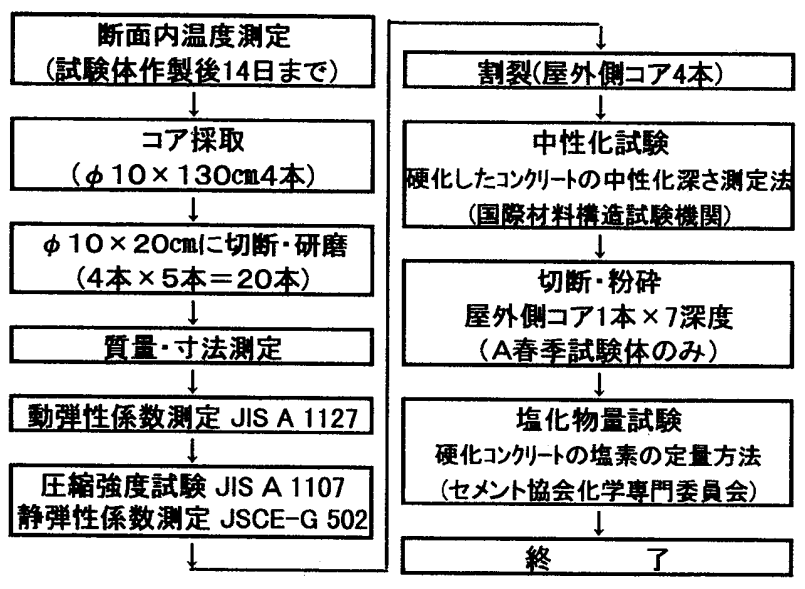

图一－A試験体での試験手順例

なお噮境調查として、暴露場における飛来塩分量の測定を試験体 暴露開始時から継続的に実施している。試験の方法については結果 とともに後述する。

\section{3. 试的䊅果}

\section{1 试駼体作"紫時の温度福歴}

A 試験体には図ー4に示す(1) (6)の位置に熱電対を設置し、打設 直後から 2 週間後までコンクリートの温度を実測した。打設季節別 の中心部（測点(3)）のコンクリート温度（打設時, 最高時）を、フ レッシュ性状とあわせて表一 4 に示す。また、中心部（測点(3)）と 上面（测点(6)）の温度履歴を図一 5 に示す。

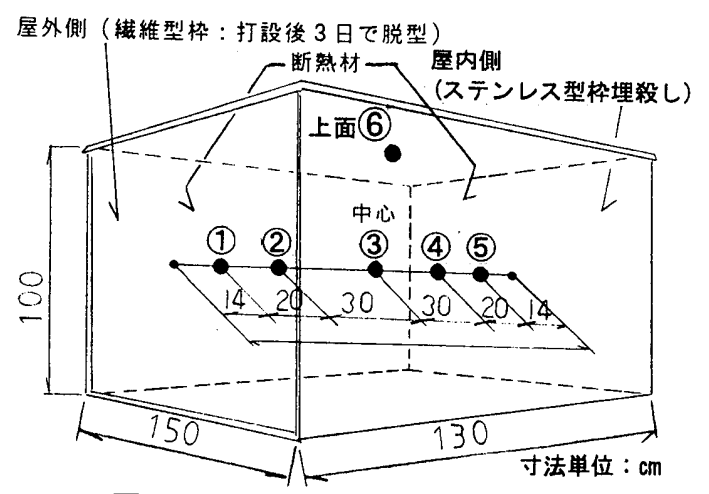

图-4 A 试験体断面内温度湘定位目

表-4 A 試験体中心部 (測点(3) 温度

\begin{tabular}{|c|c|c|c|c|c|}
\hline \multirow{2}{*}{ 打設時期 } & スランプ & 空気量 & \multicolumn{3}{|c|}{ コンクリート温度 } \\
\cline { 4 - 6 } & 打設直後 & 最高時 & 上昇量 \\
\hline 春季 & $12.5 \mathrm{~cm}$ & $3.9 \%$ & $18^{\circ} \mathrm{C}$ & $44^{\circ} \mathrm{C}$ & $+26^{\circ} \mathrm{C}$ \\
\hline 夏季 & $15.0 \mathrm{~cm}$ & $3.8 \%$ & $12^{\circ} \mathrm{C}$ & $48^{\circ} \mathrm{C}$ & $+36^{\circ} \mathrm{C}$ \\
\hline 冬季 & $13.5 \mathrm{~cm}$ & $3.5 \%$ & $13^{\circ} \mathrm{C}$ & $31^{\circ} \mathrm{C}$ & $+18^{\circ} \mathrm{C}$ \\
\hline
\end{tabular}

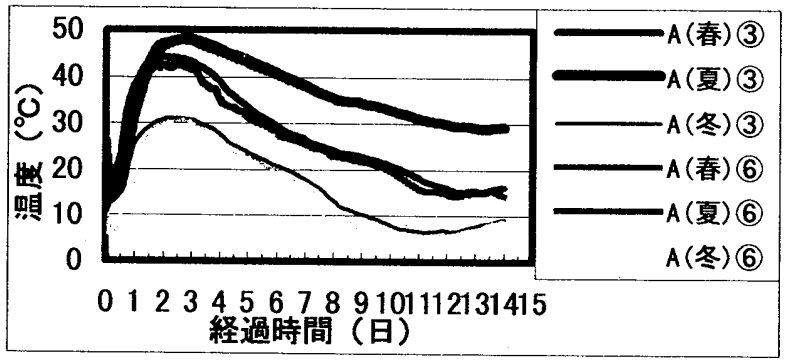

图一 5 A 试挽体 中心部(測点(3)) と上面(測点(6))の温度屡歴
各試験体とも打設後 2 日程度で最高温度に達しているが、温度の 上昇が懸念された夏季でも、打設時のコンクリート温度をプレクー リングにより $12{ }^{\circ} \mathrm{C}$ で抑制したことにより、最高温度約 $48^{\circ} \mathrm{C}$ と、 春季と比較しても大きな差がでていない。プレクーリングの効果に ついては既報の研究 ${ }^{11}$ 等により、長期強度の増進が見込めることが 確認されている。

なお、実機 PCCVでも同様の温度測定を行っているが、その結 果は $\mathrm{A}$ 試験体の測定結果とほぼ同等であった。また、試験体の中心 部(3)と上面(6)の温度履歷がほぼ同じであったことから、断熱材巻き 込み面は断熱状態が確保されていたといえる。

\section{2 压樎強度}

(1) 強度発現

$\mathrm{A}$ コア供試体及び $\mathrm{C}$ 試験体の強度発現傾向の比較を、打設季節別 に図一 6 に示す。 $\mathrm{A} コ ア$ 供試体及びC試験体それぞれの全体的な強 度発現傾向を把握するため、各材龄ごとの強度はそれぞれ 20 体及 び 3 体の平均値で示している。なお、A コア供試体 20 体の採取位 置による強度発現傾向の比較については後述する。

強度管理の基準となる標準養生のC試験体は、いずれの打設季節 も 13 週で $70 \mathrm{~N} / \mathrm{min}$ 前後を示した。それ以降の現場封絾養生での強度 発現は、材齢 2 年までは比較的增進傾向が大きく、それ以降は僅か な增進傾向を示しているといえる。ただし、冬季打設分の材跲 2 年 目では、強度が $96.3 \mathrm{~N} / \mathrm{m}^{2}$ と、前後の材齢に比べて高くなっている。 その要因の特定はできないが、試験体及び試験状況等には特に異常 はなく、個々のデー夕間に大きなばらつきはみとめられない。

一方、実機を模擬して現地暴露したAコア供試体では、打設季節 により強度発現傾向に違いがみられる。13 週の強度発現で、冬季 打設分が $52.2 \mathrm{~N} / m$ m代と他の季節と比較して遅くなっているのは、初 期の低温度履歴の影響と考えられる。

各打設季節とも、C試験体と $\mathrm{A} コ ア$ 供試体の強度は、材齡の経過 に伴って次第に近づく傾向がみられている。

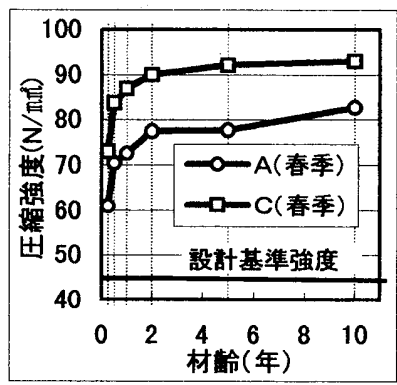

春季打設分の比較

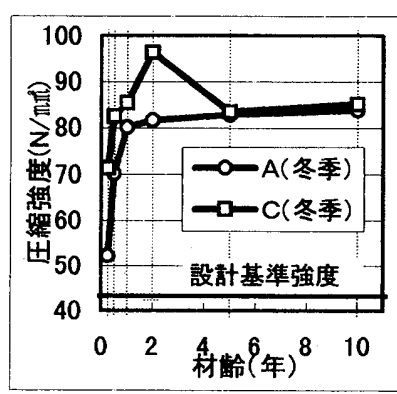

冬季打粗分の比較

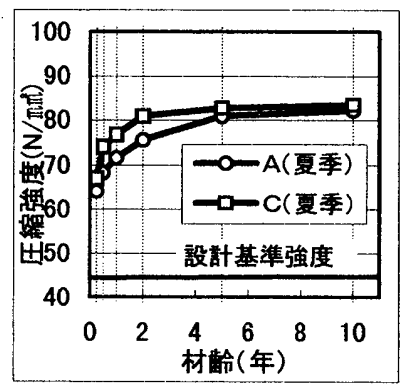

夏季打設分の比較
図一6 A コア供試体及びC試験体の强度発現の比較 
$\mathrm{A}$ 及び $\mathrm{B} コ ア$ 供試体の打設季節別の強度発現傾向の比較を図 -7 に示す。各材齢ごとの強度はいずれも 20 体の平均値で示している。

夏季打設分は 13 週までの強度発現が最も早く、その後の強度增 進は比較的小さい。冬季打設分は、13 週までの強度発現が最も遅 く、その後は材踰 1 年までの間に急増している。春季打設分はそれ らの中間的な推移を示している。いずれの季節の供試体も、材齢 5 年から 10 年にかけては強度増進が僅かであり、材龄 10 年では、初 期にみられた打設季節間の強度差がほぼなくなり、83N/mil付近に 収束する傾向を示している。

強度の増進、すなわちセメントの水和は化学反応であり、反応速 度は初期温度履歴の影響を顕著に受けるということが知られている。 打設季節ごとの強度発現傾向については、初期温度覆歴に関する一 般的な知見と一致しているといえる。

また、いずれの打設季節分も長期的に強度増進傾向が継続される のは、調合に中庸熱ポルトランドセメントとフライアッシュを用い ていることによるものと考えられる。

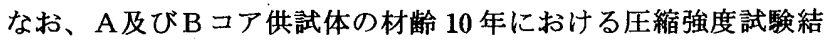
果の変動係数は $6.2 \sim 9.4 \%$ 範囲であった。

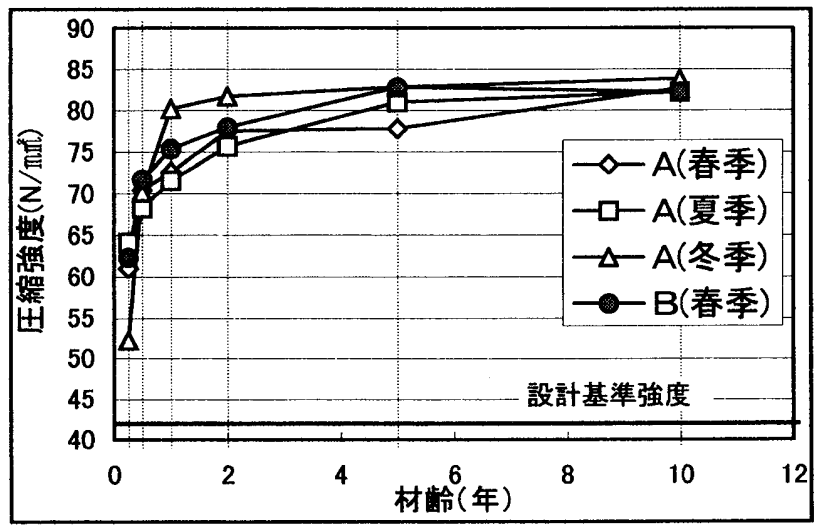

图-7 A及びB.コア供成体の強度発現傾向の比較

\section{（2）試験体断面内の強度分布}

図一8にA コア供試体の水平及び垂直各断面方向の打設季節別の 強度分布を示す。水平方向は切り抜いた供試体の位置関係が粉方向 に同じ箇所（4 体）の平均值、垂直方向は試験体から切り抜いた 1 本内（5 体）の平均值の分布である。

また強度分布と断面内初期温度履歴の関係をみるため、図一 9 に 前述のコンクリート温度測定結果による断面内水平方向各測点（1) 〜(5)）の最高温度の分布を打設季節別に示す。

水平方向については、いずれの打設季節分も中央部になるほど強 度が低下する傾向を示している。図一 9 に示すとおり、最高温度の 分布は中央部になるほど高く、強度分布と逆の傾向を示している。 最高温度には打設後 2 日程度で達しており、この初期の温度履歷が、 その後の断面内における強度增進に影響を与えていると考えられる。

垂直方向については、冬季打設分において試験体の下部になるほ ど強度が高くなる傾向を顕著に示している。特定は難しいが、要因 の一つとして、コンクリートの自重圧密効果があげられる。特に、 初期のセメント水和反応速度が最も遅い冬季打設分にその影響が顕 著に現れた可能性が考えられる

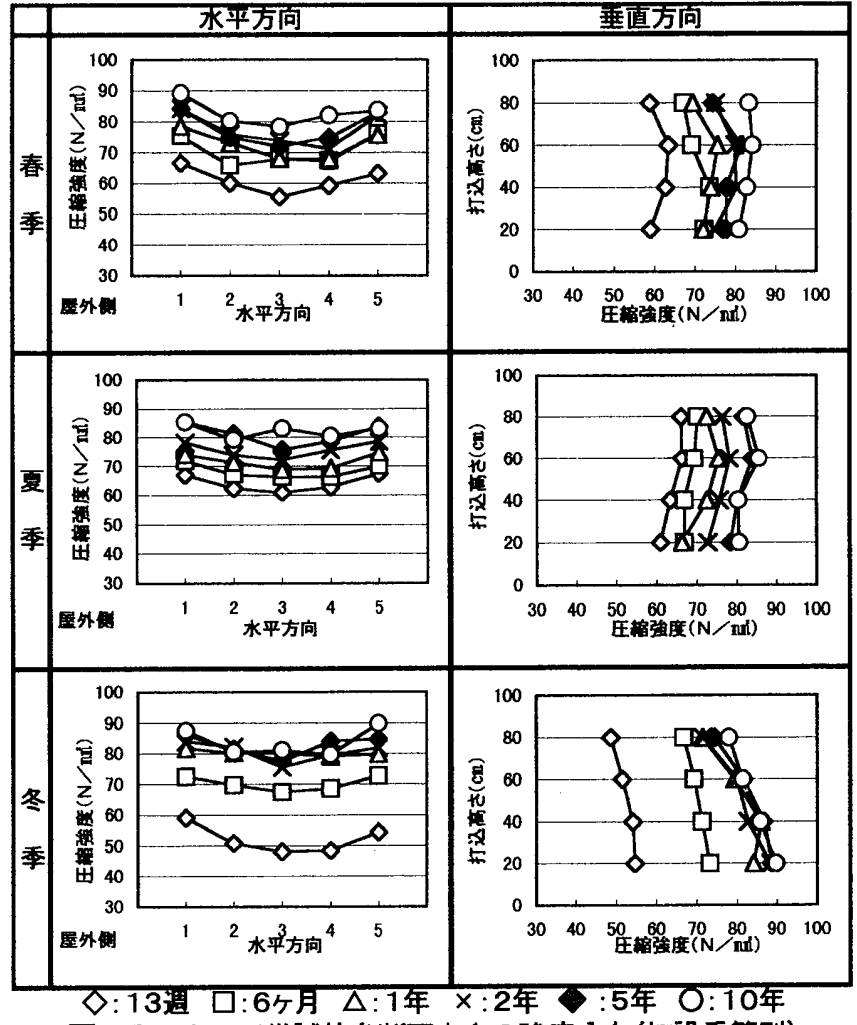

图一8 Aコア供試体各断面方向の強度分布(打設李節別)

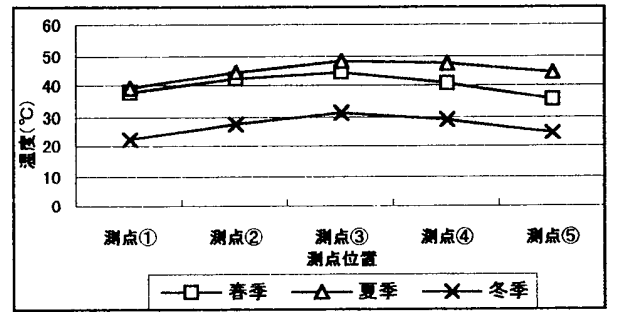

図一 9 Aコア供試体断面内水平方向の最离温度分布

\section{3 弾性你数}

図-10にA及び $\mathrm{B} コ ア$ 供試体全ての材齢 10 年目までの圧縮強度 と静弹性係数（ $1 / 3$ 応力による割線弹性係数）の関係を示す。図一 10 中には、コンクリート強度の高い範囲（設計基淮強度 $>36 \mathrm{~N} / \mathrm{mnl}$ ） で適用性がよいとされている NewRC 式”による算出結果を、比較 用にあわせて示す。当式は図一 10 中に示すとおりであるが、算出

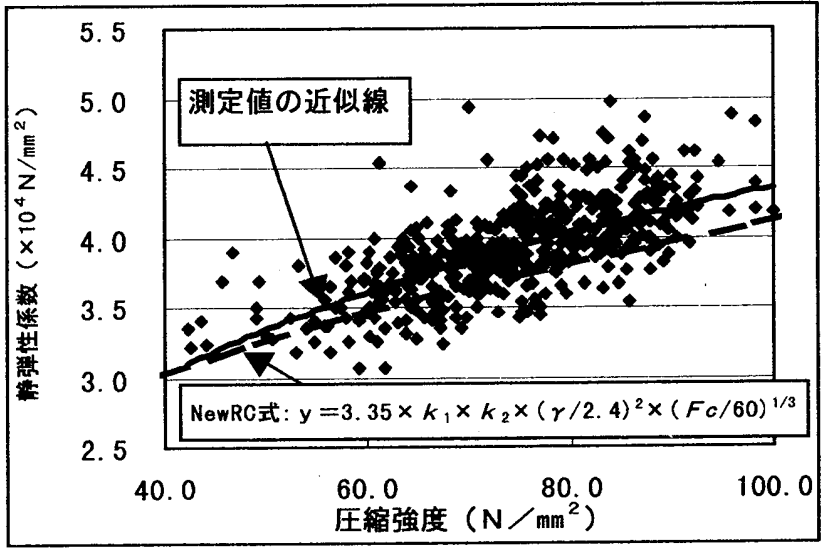

图一10 A及びBコア供試体の圧縮強度と䋫弾性係数の関係 
にあたって、 $k_{1}=1.0, k_{2}=1.1$ (フライアッシュを用いている ため)， $\gamma=2.327 \mathrm{t} / \mathrm{m}^{3}$ (調合計算値) とした。

静弾性係数は、材龄 10 年で $4.18 \sim 4.45 \times 10^{4} \mathrm{~N} /$ m⿺である。強 度との関係の傾向としては NewRC 式による算出結果と概ね類似し ている。

図ー 11 に及び B コア供試体全ての材齡 10 年目までの動弹性係 数と静弾性係数の関係を示す。一般に、動弾性係数は静弾性係数よ り $10 \sim 40 \%$ 程度大きい值を示す4)ことがいわれているが、本試験 における測定值を直線回帰で表した場合、静弾性係数より平均的に 13 \%程度大きい值を示しており、一般的なコンクリートの性状を 示しているといえる。

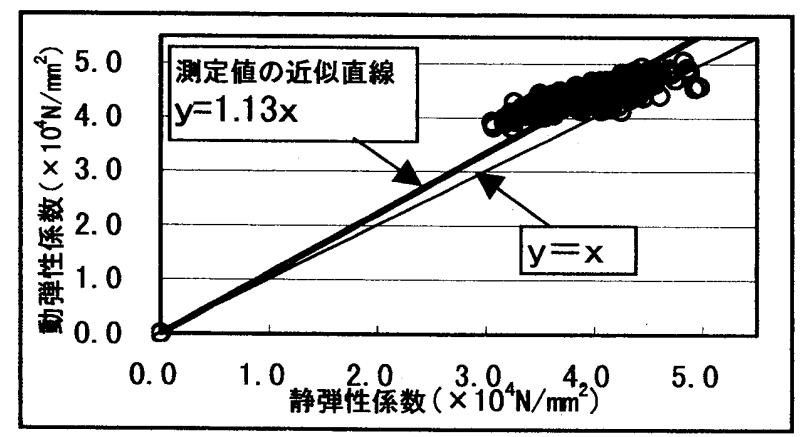

\section{図一11 A及びBコア供試体の動弾性係数と静弾性係数の関係}

\section{4 中性化深さ}

$\mathrm{A} コ ア$ 供試体（全季打設分）の屋外側面（塗装有）， $\mathrm{B} コ ア$ 供試 体の屋外側及び屋内側面（いずれも塗装無）の、それぞれ垂直方向 のコア供試体各 4 体を用いて、王縮強度試験実施後に中性化梁さ試 験を行った。暴露 10 年での測定結果は、塗装有無に関わらず全て $0 \mathrm{~mm}$ であった。表面を圧縮強度試験用に $1 \mathrm{~mm}$ 程度除去していること を考慮しても、いずれの供試体も $1 \mathrm{~mm}$ 以上は中性化していないこと となる。

当コンクリートは水結合材比が $39 \%$ と非常に小さく、さらに織 維型枠を用いていることも相乗し、表層に気泡やあばたがない堅硬 で密実性の高いコンクリートとなり、中性化の進行が抑制されてい ると考えられる。

\section{5 飛来㙁分至の測定}

試験体暴露開始時である平成元年 2 月より、暴露場において土研 式塩分ほ集器（ほ集面は $10 \times 10 \mathrm{~cm}\left(1 \mathrm{~d} \mathrm{~m} \mathrm{~m}^{2}\right)$ のステンレス板）によ る飛来塩分の測定を行っている。測定頻度は、平成 3 年 9 月までほ ぼ月 1 回、その後平成 7 年 2 月までほぼ 3 ヶ月に 1 回、その後現在 まで 6 ヶ月に 1 回である。ほ集器の測定面の向きは、当初海岸付近 の暴露場では南側（海側）、移設後は南東側（内陸側）に設置して いる。なお、 $\mathrm{A}$ 及び $\mathrm{B}$ 試験体は、屋外側面が飛来塩分ほ集器の測定 面と同方向になるよう、暴露場に設置されている。

図一 12 に累積飛来塩分量と経過日数の関係を示す。累積塩分量 が急增している部分は、平成 2 年 9 月の台風の影響である。この時 期の暴露場は移設前の海岸付近であり、台風の影響を顥著に受けた と考えられる。暴露場が移設されてからの飛来塩分量は毎年同程度 の勾配で累積している。

平成 12 年 2 月まで全期間の飛来塩分量の累計は $822.04 \mathrm{mg} / \mathrm{d} \mathrm{m}$ 、

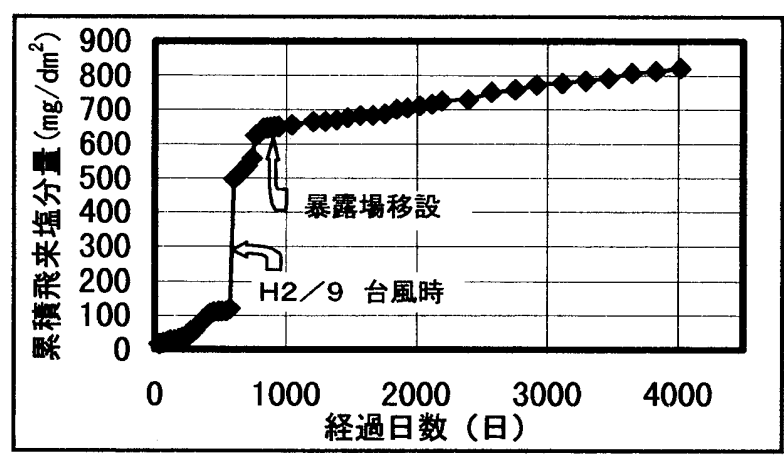

図-12 筷皘飛来塩分量と経過日数

日当たりにして $0.205 \mathrm{mg} / \mathrm{d} \mathrm{m}^{2} /$ 日であり、暴露試験体にも同様の飛 来塩分を受けていることとなる。台風の影響を除外して、暴露場移 設前後で比較すると、移設前の日当たり飛来塩分量が $0.317 \mathrm{mg} / \mathrm{d} \mathrm{m}$ /日，移設後が $0.055 \mathrm{mg} / \mathrm{d} \mathrm{m}^{2} /$ 日である。移設後の暴露場は実機 PCCVに近接しており、実機が受ける日当たり飛来塩分量は移設後 の測定值に相当すると考えらるため、実際に実機が受けた累積飛来 塩分量は暴露試験体よりも少ないといえる。

図- 13 に測定開始加ら約 2.5 年分（測定頻度 1 回／月の期間。 暴露場移設前）の月別飛来塩分量を示す。当発電所の気象観測デー 夕によると、当地の主風向きは北東で、冬型の気圧配置のときには 季節風の影響で比較的強風となる。その結果、台風の影響を除き、 12 月〜 3 月の飛来塩分量が相対的に大きくなっている。

なお、既往の測定データ例 ${ }^{5)}$ によると、冬季の日本海側では 10 $\mathrm{mg} / \mathrm{d} \mathrm{m}^{2}$ / 日を超える測定值が定常的にみられ、北陸地方における 離岸距離 $1 \mathrm{~km}$ での年平均值でも $0.3 \sim 1.0 \mathrm{mg} / \mathrm{d} \mathrm{m}^{2} /$ 日を示している。 当発電所は、地形的に海風が遮蔽されやすい立地環境にあり、その 結果飛来塩分量も低レベルで推移していると考えられる。

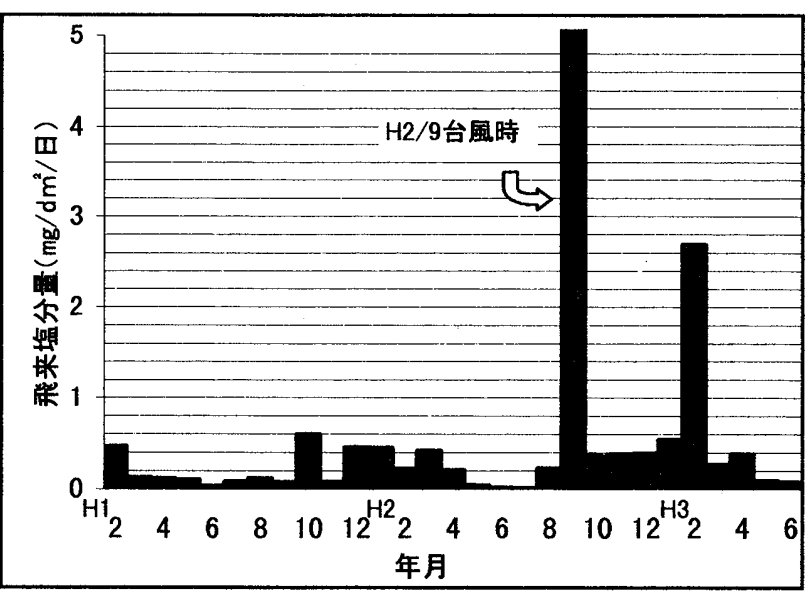

图-13 飛来塩分量の月別変轩（㢈岸距離 $10 \mathrm{~m}$ ）

\section{6 硬化コンクリート中の塭化物量}

$\mathrm{A}$ コア供試体（春季打設分）の屋外側面（塗装有）、Bコア供試 体の屋外及び屋内側面（いずれも塗装無）の、垂值方向に上から 2 段目のコア供試体を用いて、それぞれ表面から梁さ $10 \mathrm{~cm}$ 籁囲で 硬化コンクリート中の塩化物量の試験を行った。採取した粉末試料 を温水により溶解，抽出した水溶性塩分の分析により測定を行った。 
図一 14 に暴露 10 年での試酫結果を示す。全測定值は $0.023 \sim 0.070$ $\mathrm{kg} / \mathrm{m}^{3}$ の籁囲内であり、測定単位 $\left(0.023 \mathrm{~kg} / \mathrm{m}^{3}\right.$ 刻み) を考慮すると、 各条件間 (塗装の有無, 測定面の違い及び採取梁さの違い) の影著 な差異はないといえる。また同様の理由で、打設時のフレッシュコ ンクリートの測定值 $0.020 \mathrm{~kg} / \mathrm{m}^{3}$ と比較して影著な変化を示す数値 ではないと考えられる。なお、一般的に鉄筋の腐食限界の目安値は $1.2 \mathrm{~kg} / \mathrm{m}^{30)}$ といわれているが、測定值はそれに対して $2 \sim 6 \%$ 程度 である。

以上の結果から、暴露 10 年で飛来塩分が浸透蓄積している兆候 は認められず、塩害が熙念されるような状態ではないと判断できる。 無塗装面でも飛来塩分浸透の兆候がみられないのは、中性化深さの 項で述べた当コンクリート表層の密実性、及び飛来塩分量が比較的 低レベルであることが奇与していると考えられる。

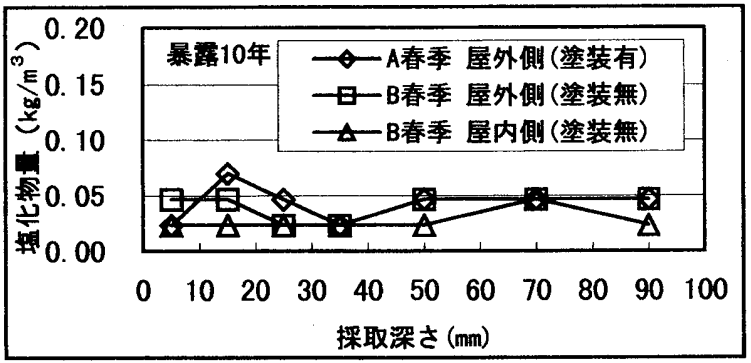

図一14 A及びBコア供試体の塩化物量

\section{7 柣蓝の性状}

$\mathrm{D}$ 試験体を用いて、硬化コンクリート中の埋設鉄筋の性状調査を 行った。試酫体は表面に実機 PCCV と同様の塗装仕上げとしたも の及びコンクリート打ち放しとしたものの 2 種類を用い、試験体か ら取り出した鉄筇について、発錆面積率及び錯落とし後の質量减少 率を調查した。暴露 10 年での結果は、発錆面積率の最大值は塗装 有りの場合 $1.6 \%$ (かぶり厚さ $4 \mathrm{~cm}$ 部), 染装無しの場合 $2.6 \%$ (か ぶり厚さ $8 \mathrm{~cm}$ 部)、質量减少率は全て $0.1 \%$ 以下であった。塗装無 しの場合、かぶり厚さの最大部で発錆面積率が最大となったが、各 かぶり厚さの測定値のばらつきが小さく、状態も浮き錆程度である ため、特異とされる状況ではないと考えられる。また鉄筋の状態か ら、試験体作製後に腐食が進行している兆候はみとめられず、中性 化及び塩化物量の試験結果と整合しているといえる。

\section{8 舆さ変化}

$\mathrm{E}$ 試験体を用いて、コンクリートの長さ変化の測定試験を行った。 この測定は、アルカリ骨材反応による異常膨張等を簡易にモニタリ ングする目的で行った。図一 15 に長さ変化率（試験体の初期長さ に対する膨張，収縮量の比率）の経年推移を示す。図の試験結果は、 試倹体 5 体の平均值である。最大变化率は収縮側に約 $0.03 \%$ 、 異常な膨張は全く認められていない。経年的な推移は、材齢 5 年ま

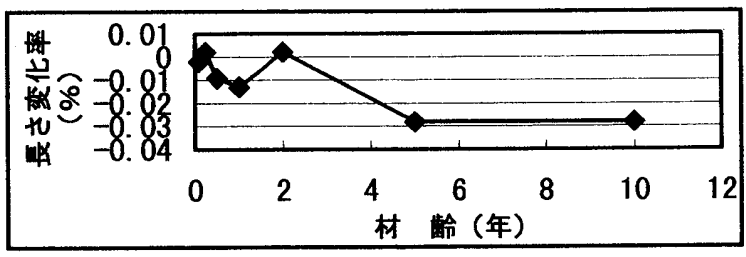

图ー15 E试験体コンクリートの長さ变化事と材龄の関係
での間にわずかな収縮が観測され、その後はほとんど変化せず、材 齢 10 年では収束状態にある。測定された最大長さ変化率は、既往 の指針類 ${ }^{\text {() }}{ }^{\text {) }}$ に示される判定値と比較して非常に小さい值となって いる。

\section{4.まとめ}

コンクリート試験体を長期モニタリングし、各種試験を行うこと により、長期的な物性変化を観察できた。

結果を以下にまとめる。

（1）実機を模擬して現地暴露した試験体の 13 週圧縮強度は、標準養 生と比較して、打設季節間の差異が影著であり、盖生条件の違いに よる影響がみられるが、いずれも設計基淮強度 $44.1 \mathrm{~N} /$ 㕰を大きく 上回っている。

(2) 現地暴露した試験体の圧縮強度は、いずれの打設季節分も材龄 10 年まで強度增進がみられ、中庸熱ポルトランドセメントやフラ イアッシュを用いていることによる特徴がみとめられる。

打設季節閒の強度発現㑯向について、材齢 5 年目までは、初期に 受けた温度履歴の違いが強度発現に影響を及ぼしているとみられる。 すなわち、初期に受けた温度履歷が最も低い冬季打設分は、他の季 節と比較して材齢 13 週の強度が最も小さいが、その後の增進が大 きく、材齢 $1 \sim 5$ 年目の強度は春季及び夏季打設分を上回っている。 ただし、材齢 10 年ではほぼ差がなく収束していることから、本試 嗝の範囲では、初期に受けた温度履歴の違いは材齢 10 年という長 期的な強度発現には大きな影響を及ぼさないと考えられる。

(3) 断面内の圧樎強度分布は、初期にコンクリート温度の高い断面 中央部とやや低い端部との間で若干の差異がみられるが、今回のよ うな $1.3 \mathrm{~m}$ と断面の厚いコンクリートにおいて、水和熱の影響を顕 著に受ける夏季打設分でも、長期の強度增進が得られている。フラ イアッシュ混合やプレクーリングの効果が寄与しているものと考え られる。

(4) 暴露 10 年が経過しても、無塗装面でも中性化の進行や塩化物の 浸透の兆候がみとめられない。当地の飛来塩分が低レベルであるこ と、及び低水結合材比と瀻維型枠の適用による当コンクリート表層 の密実性の高さにより、それらが抑制されていると考えられる。

(5) 実機 PCCV のコンクリートにおいても、試験体と同等の性状を 有していると考えられることから、健全で高い耐久性を保っている と推測される。

今後も模擬試験体によるモニタリングを継続し、重要構造物であ る PCCV コンクリートの性状を確認するとともに、適正な維持・ 管理に努めていきたい。

\section{[差考文献]}

1) 坂本哲朗, 古和田明, 牧野浩保, 竹内徹, 中根淳, 川口徹; 高強度又スコンクリート 部材強度特性に関寸る研究 (その 2 夏季試験の実施), 日本建筑学会大会学術 講演便概集, 1987 年 10 月

2) 日本建策学会 ; 構造体コンクリ一強度に関寸る研究の動向と問題点,1987 年 3）日本建築学会 ; 鉄筋エリクリー構造計算規準・同解説, 1999 年

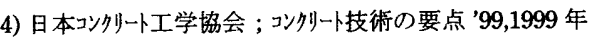

5) 藤原稔，田中良樹; 特集 *鉄筋コリクリー十構造物の塩害劣化一外部からの塩化 物一, コンクリ以下学, 1987 年

6) 岸谷孝一，西澤紀昭他編；塩害 ( I ),1986 年

7) 日本建築学会 ; 建築工事標準仕様書・同解説 JASS5N 原子力発電所施設に おける鉄笳コ归-卜工事 T-603,1991 年

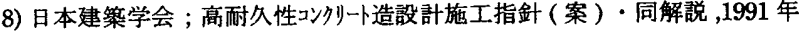

[2000年10月20日原稿受理 2001年 2 月22日採用決定］ 